\title{
Liberal Medya Okuryazarlığı Kavramsallaştırmasına Eleştirel Bir Bakış
}

BaşvuruTarihi: 09.11.2020 Yayın Kabul Tarihi: 08.12 .2020 Yayınlanma Tarihi: $\quad 30.12 .2020$

\author{
Ayşe Elif Emre Kaya ${ }^{1}$ \\ Ankara Hacı Bayram Veli University \\ elifemrekaya@gmail.com \\ ORCID: 0000-0002-9367-034X
}

\begin{abstract}
ÖZET
Kavramların gücü, üzerlerinde konsensüse vardığımızı kuvvetli bir biçimde hissettirmelerinden gelmektedir. Kavramların tanımlandıkları biçimleri kapsadıklarına dair inanç, onlara duyulan güveni artııır, böylelikle toplumda yerleşiklikleri kolaylaşır. Burada kavramları belirleyen güçlere odaklanma gereği ortaya çıkar. Çünkü kavramlar, etkili görünseler de kendileri de güç iktidar ilişkileri çerçevesinde belirlenmektedirler. Bu bakış açısı medyaya ilişkin epistemolojik birikime ve buna yön veren yapıya odaklanılmasını zorunlu kılmaktadır. Medya ve medya okuryazarlığı kavramsallaştırılmalarında, liberal medya anlatısının hâkimiyeti vardır. Liberalizmin mevcut yapının muhafazası biçiminde işleyen, dolayısıyla sorgulama ve üretme gibi etkinlik alanlarını oldukça sınırı tutan yaklaşımı, medya ve medya okuryazarlığı kavramsallaştırılmalarında aynen benimsenmiş, tanımında ileri sürülen potansiyelleri barındırması yapısal olarak imkân dışı kalmıştır. Liberal anlatılarda, medyanın kapitalist pazar ile bağı gizlenmekte, hatta eleştirel olduğunu iddia eden medya okuryazarlığı kavramsallaştırılmalarında dahi bu bağ ya kurulmamakta ya da silik tutulmaktadır. Bu kavramsallaştırmanın eleştirel bir düşünümsellik barındırması için, kapitalist üretim tarzı ve işleyiş biçimlerinin medyaya ve medyaya içkin kavramsallaştırmalara etkisinin göz önünde tutulması ve bunları dönüştürebilecek düşünceler içermesi gerektiği düşünülmektedir.

Medya okuryazarlığı kavramını ve kavramsallaştırmasını bütün bu düşünceler ışı̆ında ele alma niyetinde olan bu çalışmada, medya okuryazarlığııın nasıl kavramsallaştırıldığından yola çıkılarak, tanıma nelerin eklenip, nelerin tartışma dışında tutulduğu üzerinde durulmuştur. Betimleyici nitelikteki çalışmada, ekonomik ve kültürel yapıyı birbirinden ayırmayan eleştirel medya/kültürel çalışmalar perspektiften bakılarak eleş̧tirel bir yaklaşımla, medya okuryazarlığı kavramsallaştırılmasının ekonomi politik bağları ortaya serilmiş, böylelikle kavramın sistem içerisinde üstlendiği role ve işleve dikkat çekilmiştir.
\end{abstract}

Anahtar Kelimeler: Medya, Liberal Medya Kuramları, Eleştirel Medya Kuramları, Medya Okuryazarlığı.

${ }^{1}$ Doçent Doktor. Ankara Hacı Bayram Veli Üniversitesi. 


\title{
A Critical Perspective On Liberal Media Literacy Conceptualization
}

Ayşe Elif Emre Kaya²

Ankara Hacı Bayram Veli University

elifemrekaya@gmail.com

(iD) ORCID: 0000-0002-9367-034X

\begin{abstract}
The strength of the concepts comes from the strong feeling that we have reached consensus on them. The belief that concepts include the forms in which they are defined increases the trust felt in them, thus facilitating their settling in society.At this point, the need arises to focus on the forces that determine the concepts. Because even though the concepts seem effective, they are also determined within the framework of power-power relations. This perspective necessitates the focus on the epistemological accumulation of media and the structure that guides it. The liberal media narrative dominates in the media and media literacy conceptualizations. The approach of liberalism, which operates as the preservation of the existing structure, thus restricting the fields of activity such as questioning and production, has been adopted exactly in the conceptualization of media and media literacy, and it has been structurally impossible to accommodate the potentials put forward in its definition. In liberal narratives, the media's ties to the capitalist market are hidden, and even in the media literacy conceptualizations that claim to be critical, this link is either not established or kept obscured. In order for the concept of media literacy to bring about a truly critical reflexivity, it is thought that the effect of the capitalist mode of production and functioning on the media and media inherent conceptualizations should be taken into account and it should include ideas that can transform them.

In this study, which is based on the intention of addressing the concept and conceptualization of media literacy in the light of all these thoughts, it is focused on what is added to the definition and what is excluded from the discussion, based on how the concepts of media and literacy are conceptualized. In this descriptive study, the political economy ties of the conceptualization of media literacy have been revealed with a critical interpretative approach, based on the perspective of critical media / cultural studies that do not separate the economic and cultural structure, thus drawing attention to the role and function of the concept in the system.
\end{abstract}

Keywords: Media, Liberal Media Theories, Critical Media Theories, Media Literacy.

\footnotetext{
${ }^{2}$ Associate Professor. Ankara Hacı Bayram Veli University.
} 


\section{Giriş}

Tanım, Türk Dil Kurumu sözlüğünde, bir kavramın niteliklerini eksiksiz olarak belirtme veya açıklama, tarif olarak ifade edilmektedir ${ }^{3}$. Bu açıklamayı nötr bir izah kabul etmeyip, bir kavramsallaştırmanın basit bir nitelik belirlemesinden fazlasını içerdiğini ve yapılan tanımların boş levhalar gibi asılı durmaktan ziyade, niyetli çerçeveler olduğunu düşündüğümüzde, kavramları farkı bir açıdan tartışmak zorunlu hale gelecektir. Daha açık bir deyişle, kavramların tanımlanmasının; o kavramın olası pek çok açılımı olabilecek iken, bir anlamda sabitlenmesi gayreti olduğu ve bu gayretin de ekonomi politik şartlarla belirlenen güç ve iktidar ilişkilerinden bağımsız olmayan bilinçli bir çaba olduğunu fark ettiğimizde, tanım ve kavramsallaştırmalara zihinsel haritalandırmalarımızda gönül rahatlığıyla kendimizi teslim etme anlayışımızı gözden geçirmemiz gerekecektir. Bu bakış açısı, kavramları apriori olarak nötr kabul etme geleneğini bir yana bırakarak, tanımların kavramsallaştırmalarının gerisindeki ideolojik niyetleri görmeyi sağlayacak ve alternatif kavramsallaştırmalara gidildiğinde de nasıl bir mücadele haritası izlenebileceğine dair ipuçları sunacaktır.

Bu çalışma, medya okuryazarlığı kavramını ve kavramsallaştırmasını bütün bu düşünceler ışığında ele alma niyeti üzerine kuruludur. Medya okuryazarlığına ilişkin kavramsallaştırmalar ortaya konarken, medya ve okuryazarlık kavramlarının nasıl tanımlanıp, kavramsallaştııılığından yola çıkılarak, tanıma nelerin eklenip, nelerin tartışma dışında tutulduğu yorumlanacak, medya okuryazarlığı kavramsallaştırması ile hedeflenenler incelenecektir. Betimleyici nitelikteki bu çalışmada, ekonomik ve kültürel yapıyı birbirinden ayırmayan eleştirel medya/kültürel çalışmalar perspektifinden hareket edilerek, eleştirel bir yaklaşımla, medya okuryazarlığı kavramsallaştırılmasının ekonomi politik bağlarının ortaya çıkarılarak, kavramın sistem içerisinde üstlendiği rolüne ve işlevine dikkat çekilmesi hedeflenmektedir. Çalışmada medyanın ve dolayısıyla ona ilişkin üretilen medya okuryazarlığı kavramsallaştırmasının, topluma hâkim olan üretim düzeni ve kurduğu anlamsal dünya ile bağının yok sayıldığı, dolayısıyla bu üretim biçimine hâkim sınıfların zihinsel biçimlendirmelerden etkilenmediği anlatısının, medya ve ona ilişkin üretilen kavramsallaştırmalara egemen olduğu düşüncesi hâkimdir. Çalışma, bu kuramsal duruşuyla, medya okuryazarlığı kavramı ve kavram ile birlikte ortaya konan toplumsal dönüşüm hedeflerinin ekonomik ve politik bağlarını kurarak, illüzyonlara dikkat çekip, gerçek nitelikte bir farkındalık oluşturmakta ve medyanın liberal okuryazarlığını altüst ederek, eleştirel nitelikte bir medya okuması yaparak alana katkı sağlamayı hedeflemektedir.

\section{Medya Okuryazarlığı Kavramı}

Bir kavramın tanımlanması, onun zihinlerde nasıl yer alacağının sınırlarını çizmek çabasıdır. Bir başka deyişle, kavram açıklanırken, aslında zihinlerde başka bir anlama gelmeyecek biçimde

\footnotetext{
${ }^{3}$ https://sozluk. gov.tr/? kelime=akl\%C4\% B1nda \%20kalmak
} 


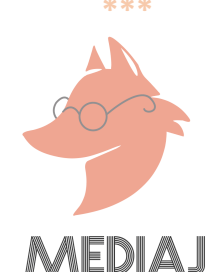

sabitlenmeye çalışılır. Bu süreç, bağımsız ve birbirine muhalif güçlerin orantılı bir biçimde yarıştığı bir eylem olarak gelişmez, toplumda egemen olan üretim biçimi ve bu üretim biçiminin hâkim sınıfları, zihinlerin biçimlendirilmesinde çoğu zaman belirleyici olur. Bu nedenle, bir kavrama ve onun toplumda kullanma biçimine bakarken, bu durumu göz önünde tutmak gereklidir. Aksi halde kavramları nötr kabul edip, onların içlerine gizlenmiş yapısal yanlılık biçimlerini görmeyerek bilinçli/bilinçsiz bir şekilde egemen ideolojinin yeniden üretimine ve hatta güçlenmesine katkı sağlamış oluruz.

Medya okuryazarlığı kavramını, ilk olarak gramer yönünden incelemeye başlarsak, bunun basit bir isim tamlaması ${ }^{4}$ olarak figüre edildiği görülmektedir. İsim tamlamaları gramerde "aitlik" ilişkisi kurmaya yarayan bir sistemdir. Hatta tamlamaların bazılarında aitlik durumu daha da belirgin hale getirilmekte ve belirtili isim tamlaması oluşturulmaktadır. Belirtisiz isim dediğimiz bir diğer tamlama biçiminde ise, bir ismin başka bir isme ait ilişkisinin kurulmasından çok, bir nesne ya da kavram ismi oluşturmak burada esastır. Konuya ilişkin verilmiş bir örnek bu durumu daha net bir biçimde ortaya koymaktadır: "Çocuğun elbisesini alacağız" cümlesindeki "çocuğun elbisesi" tamlaması belirtilidir. Bu tamlamada belli bir çocuğa ait elbiseden söz edilmektedir. Bu tamlama, "Çocuk elbisesi alacağız" şeklinde söylendiğinde bu durumda belli bir kişiye ait elbiseden değil, genel bir elbise çeşidinden "çocuk elbisesi"nden söz etmiş oluruz ve "belirtisiz isim tamlaması" yapmış oluruz ${ }^{5}$.

Belirtisiz bir isim tamlaması olarak figüre edilen medya okuryazarlığı kavramının, gramer kurallarına bakıldığında, bir aitlik ilişkisini belirgin bir biçimde kurmaktan ziyade, bir nesne ya da kavram ismi oluşturmak amaçı tasarlandığı görülmektedir 6 . Yani medya okuryazarlığı, bir nesnenin zihindeki tasarımlanmış biçimidir. Bu tasarımda belli bir "medya"ya değil, genel bir medyaya işaret edilmektedir. Kelimenin tamlayan ve tamlanan kısmına bakıldığında, tamlayan medya kelimesidir ve vurgu dolayısıyla da ondadır. Okuryazarlık medyadan biçimlenen ve etkilenen bir durumdur. Medya kavramının içine dahil edilen anlamlar ya da ona ilişkin dışarıda bırakılan bütün düşünceler, okuryazarlık kavramını ve dolayısıyla buna bağlı olarak kapsamı etkileyecektir. Dolayısıyla medyanın tanım ve kavramsallaştırması onun okuryazarlık formatını belirleyecektir.

Kavram yapısal olarak inşa edilirken, önemi, medyaya evrilir bir biçimde dizayn edildiği için, ilk

\footnotetext{
4 İsim tamlaması, "bir ismin aitlik ilgisi yönünden daha belirgin hâle gelmesi için başka bir isim tarafından tamamlanmasıyla oluşan isim grubuna isim tamlaması" olarak tanımlanmaktadır. Tamlayanın ilgi eki, tamlananın da iyelik eki aldığı tamlamalardır. İnternet Adresi: https: // www.dilbilgisi.net/tamlamalar-konu-anlatimi/ Erişim Tarihi: 26.03. 2020).

5 https: // www.dilbilgisi.net/ tamlamalar-konu-anlatimi. Erişim Tarihi: 26.03.2020. Konuya ilişkin diğer bilgi ve örnekler https://bilgiyelpazesi.com/ egitim_ogretim/konu_anlatimli_dersler /turkce_ dersi_ile_ ilgili_konu_ anlatimlar/belirtisiz_isim_tamlamasi_ozellikleri.asp/internet adresinden 26.03. 2020 tarihinde alınmıştır.

6 Bu noktada kavram kelimesi nedir diye baktığımızda, kavram nesnelerin zihinlerdeki tasarımı olarak ifade edilmektedir. İnternet Erişim Adresi: https://kavram.nedir.org/Erişim Tarihi: 26.03.2020.
} 
olarak medya kavramına odaklanılacak ve medyaya ilişkin kuramsal tartışmalar hatırlatılacaktır. Bunu yaparken kavramla olan bağı kurmaya da bir yandan devam edilecektir.

\section{Medya Kavramı}

Medya TDK sözlüğüne göre; iki şekilde tanımlanmaktadır: "1. İletişim ortamı 2. İletişim araçları”. iletişim ortamı, haberleşme veya komünikasyon imkânlarının sağlandığı ortam" olarak açıklanmıştır ${ }^{8}$. Bir diğer tanımda ise, medyanın enformasyon, farkındalık yaratma, eğitim, toplumsallaştırma, eğlendirme ve gündem belirleme gibi işlevlere sahip, her türlü sözel, yazılı ve görsel imgenin dahil olduğu tüm iletişim araçlarını kapsayan bir terim olarak ifade edilmiştir ${ }^{9}$. İlk tanım ile ikinci tanım arasında, kavrama katılan anlamlar arasındaki fark ortadadır. İki tanımda da medyanın iletişim kurulmasını sağlayan bir araç olduğu bilgisi söz konusudur fakat ikinci tanımda medyaya yüklenen işlevler onu başka bir çerçeveye taşımaktadır. Medyaya yüklenen işlevler ve anlamını tartışmaya geçmeden evvel, şu noktaya bakmakta fayda bulunmaktadır.

Yukarıdaki iki tanım da medyanın "araç" yönüne ilişkin bir vurguyu içermektedir. Bu anlatı, basit bir öne çıkarmadan ziyade, içinde önemli bir ideolojiyi barındırmaktadır. Parçayı, bütünün temsili olarak kabul etme geleneği, teknolojik ürünün teknolojik üretim yapısının tamamına işaret ettiği anlatısı, burada da harekete geçirilmektedir. Daha açık bir deyişle, biz medyayı konuştuğumuz zaman, medyayı "üreten makine, emek, bilgi ve ilişki düzenini yani teknolojiyi" mi konuşuyoruz, "bu teknolojinin ürününü" mü kastediyoruz (Erdoğan, 2000, s. 292), bunu netleştirmemiz gerekmektedir. Tanımın kavramsallaştırmasında bu noktanın belirgin hale getirilmesi, kavramın nasıl bir çerçevenin içinde sabitlenmesine çalışıldığına dair önemli bir ipucu taşıdığı için, bu konuya ve cevabına odaklanılması şarttır. Medyayı sadece teknolojik bir ürün olarak tanımladığımızda içinde üretildiği üretim biçim ve koşullarından, emek, bilgi ve ilişki biçimi ile olan bağlarını koparttığımız bir noktaya taşımış oluyoruz. Bu durum da doğal olarak, onu, yapısal bağlarından soyutlayarak, "değer yargısız" bir alana yerleştirme adına ideolojik bir işlevsellik yaratmaktadır. Daha açık bir ifadeyle bu anlatımda teknolojik ürün, hiçbir bağı ve belirleyeni olmayan, kendisi hatta belirleyen olabilme yetisine sahip bir araç konumuna yerleşmektedir.

Bu konuda ülkemizde medya okuryazarlığı projesi kapsamında hazırlanan ders kitabındaki ifadeleri hatırlarsak; yukarıdaki anlattıklarımızı somutlaştırmak mümkün hale gelecektir:

Medya, kitapta, "çeşitli çok sayıda iletiyi bireye ve topluluklara aktaran, eğlendirme, bilgilendirme ve eğitme gibi üç temel sorumluluğa sahip, görsel, işitsel, hem görsel hem işitsel araçların tümüne medya diyoruz"... şeklinde tanımlanmış, ardından medyanın üç boyutu

\footnotetext{
${ }^{7}$ Tanım için bkz. İnternet Erişim Adresi: https://sozluk.gov.tr/ Erişim Tarihi:01.04.2020.

8 Internet Erişim Adresi: https://kelimeler.gen.tr/iletisim-ortami-nedir-ne-demek-162952. Erişim Tarihi: 01.04. 2020.

${ }^{9}$ Internet Erişim Adresi: https://www.igi-global.com/dictionary/the-understanding-of-entertainment-in-pressenterprises-in-turkey/18142. Erişim Tarihi: 02.04.2020.
} 


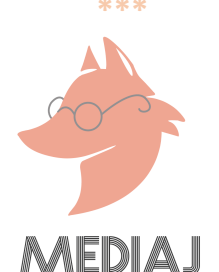

olduğundan bahsedilmiştir: 1. Teknoloji - üretim ve kullanıma sunulma süreçleri, 2. Toplumsal ilişkiler - profesyoneller medya örgütleri ve medya endüstrisinin iç işleyişi ile diğer örgütler ve toplumsal kurumlarla ilişkileri, 3- Kültürel biçimler, ürünler - gazetelerin, programların vb.; dolaşıma girme, okurlar ve izleyiciler tarafından alımlanma süreçleri. Kitapta bunun ardından şu bilgiler eklenmiştir:

“...bunun gibi görüşler olmasına rağmen, medya deyince ilk akla gelen televizyon ve gazetelerdir. Bunlar insanların bilinçlenmesine ve olayları takip etmelerine yarayan birer araçtır. Medya, bireylerin siyasi tutum ve davranışlarını etkileyebilecek bir güce sahiptir. Medya yalnız bireylerin siyasi yönelimlerini etkilemekle kalmaz, siyasi karar organlarını siyasi liderler ve hükümetleri de etkiler. Bundan dolayı medyaya "dördüncü kuvvet" de denmektedir" (Komisyon, 2009, s.27).

Yukarıdaki tanımın ilk bölümünde medyanın "araç" olduğu vurgulanmış, ardından medyanın boyutları sıralanarak, kendisinin de üretilmiş bir maddi ürün olarak üretim ilişkileri, işleyişi ve toplumsal bağı olduğuna ilişkin üç boyutu olduğu ifade edilmiş olmasına karşın, bunların bir "görüşten ibaret" olduğu, medya denilince bunların değil, akla yalnızca araçların geldiği vurgusu yapılmıştır. Yukarıda tartıştığımız nedenlerle, medyanın ekonomik bağı tanım metninde bir gerçeklik alanına olarak işaret edilmekten çok, "görüş" olarak imlenerek zayıflatılmıştır. Teknolojinin değil, teknolojinin ürününün konuşulmasına dair kuramsal bakış açısı ile, üretim yapısı ve ilişkilerinin belirleyiciliği konusu silikleştirilmiş, meşhur sorunun yani "değişimin belirleyici etkeni nedir? "in cevabı olarak teknolojik ürün gösterilerek, pazar içerisinde sahte dengeler kurulabilmesinin ve eşitsizliklerin üstünün örtülebilmesinin yolu açılmıştır. Bir yandan mevcut olumsuzlukların kaynağının üretim ilişki ve yapısı olduğu tartışmasını başarı ile gizleyen teknolojinin kalkınma ve gelişmeyi saptadığı görüşü, öte yandan da kalkınma için teknoloji transferlerinin gerekli olduğu düşüncesi pazarlanmıştır (Alemdar ve Erdoğan, 1998, s.105). Oysa ülkelerin gelişme ve kalkınmasının çözümü olarak sunulan bu transferlerde, transfer edilen yalnızca "ürün" olmuş, buna direnebilecek kültürel alan da zihinsel yönlendirmelerle manipüle edilerek, kapitalist olmayan ülkelerin bă̆ımlılıkları garantilenerek, model, kapitalist sermayeyi kalkındırma işine yarar şekilde işletilmiş $(1998$, s.105) ve ardındaki anlatı yapısı da olumlanarak yerleşikleştirilmiştir. Dolayısıyla, sosyal ve ekonomik güç yapısıyla bütünleşik olan iletişim teknolojisi, benzer bir biçimde biçimlenmiş ve bu ideolojik çerçeve medyayı "araç" boyutunda tartışma ile sınırlı bıraktırmıştır.

\section{Medyaya ilişkin Farklı Kuramsal Yaklaşımlar}

Medyanın toplumsal gerçeklikle olan bağı, farklı kuramsal bakış açılarında farklı şekillerde kurulmaktadır. Bu noktada tek tek medyaya ilişkin ortaya konan bu bakış açılarını hatırlamak, medyaya ilişkin tanımlar yoluyla inşa edilen zihinsel haritaları ve ardındaki niyetleri görmemize kolaylık sağlayacaktır. 
Medyaya ilişkin kuramsal bakış açılarından ilki, liberal çoğulcu medya kuramıdır. Buna göre;

\begin{abstract}
"Medyanın toplumsal gerçekliği olduğu gibi aktardığı ve yansıttığı görüşü, liberal çoğulcu medya kuramı çerçevesinde öne sürülür. Buna göre, medya edilgin bir biçimde, dünyaya kendi imgesini geri verir ya da gösterir. Bunu yaparken de farklı politik görüşler ve sistemler farklı yaşamlar, kimlikler ve seçimlere ilişkin dünyada var olan bütün çeşitliliği ve çoğulculuğu sunduğu varsayılır. Toplumsal alanda var olan çeşitliliğin ve çoğulculuğun medya tarafından olduğu gibi temsil edildiği öne sürülür. Bu doğrultuda medya toplumsal durumlara kesimlere ve görüşlere eşit ölçüde açık bir aracı ortam olarak kendisini toplumsal sorumluluk ilkesi doğrultusunda yasama, yargı ve yürütmenin dışında dördüncü güç olarak konumlandırır. Kamusal tartışmaların forumu ve farklı fikirler arasındaki çatışmaların çözümünü arayan bir kurum olarak medyaya liberal sismin sürdürülmesinde pay biçilir. Bu temel öncüllerden anlaşılacağı üzere, toplumsal alan sınıfsal güç ilişkilerinden ve buna dayalı mücadelelerden muaf olarak tasarlanır. Dolayısıyla medya toplumsal çatışmaları düzenleyen ve toplumsal uzlaşım için zemin yaratan bütünleştirici rolü ile öne çıkar. Medyanın statükoyu destekleyici ve aşamalı toplumsal dönüşümlerde uyumlaştırıcı işlevi sayesinde sınıf çatışmasız bir toplumsal gerçeklik alanı kitlelerin önünde belirir" (Dursun, 2013, s. 39).
\end{abstract}

Bu tanımın da ortaya koyduğu üzere, yukarıda medya okuryazarlığı projesi kapsamında hazırlanan kitaptan alınan medya tanımı, görüldüğü gibi, liberal çoğulcu medya kuramının epistemolojik ve aksiyolojik bakış açısı ile üretilmiştir. Dolayısıyla onun ideolojik duruşu olan, mevcut durumun muhafazası şeklinde işleyen statükocu bakışı onunla beraber burada sorgusuz yer bulmaktadır. Bu bakış açısına göre; liberal medya kuramında medya araçtır, serbest piyasanın ana argümanında olduğu gibi, müdahaleye maruz bırakılmadığı zaman "yansızdır", "özgürdür". Buradaki olası müdahalenin kaynağı da aslında oldukça nettir. Şöyle ki, serbest pazar bunun zihinsel izdüşümü liberalizme göre; bu alanın mükemmel işleyişini bozabilecek tek kaynak devlettir. Medya devletin ya da siyasal partilerin etkilerine maruz kalmadığı hallerde, çeşitliliğin ve çoğulculuğun temsilinin önünde yapısal engeli barındırmaz, farklı fikirlerin varlığı ve serbest dolaşımı ile toplumsal uzlaşmanın sağlanmasının yolunu açar. Liberal çoğulcu medya kuramı bütün bu yönleriyle, çatışmasız bir toplum düzenini kurguladığından, mevcut düzenin devamlılı̆ına da dolayısıyla vurgu yapar.

Bu anlatıda görüldüğg̈ü gibi, idealize edilmiş bir medya ortamı bulunmaktadır. Medyanın özellikle bilgilendirme ve habercilik faaliyetleri göz önünde tutularak, medyaya diğer bütün meslek ve profesyonelliklere göre farklı bir önem atfedilmiş ve demokrasinin en güçlü bileşenlerinden biri olarak medya faaliyetleri kamu hizmeti halesi ile kutsanmıştır. Bu kuramsal bakış açısında eksik bırakılan, medyanın onu belirleyen koşullar ile bağının yok sayılması ya da bu bağın, içeriğin üzerinde etkisinin geçiştirilmesi ya da başka bir çerçeve içine yerleştirilerek sunulmasıdır. Komisyonun kitabında verdiği tanımında olduğu gibi, medyanın ticari bağından ve içinde 


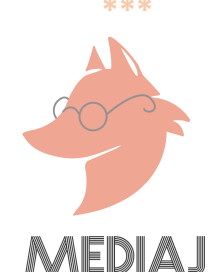

üretildiği sistemden bahsedilme hallerinde de bu görüşün yanında profesyonelliğe bağlı medyanın ticari niteliğini geri planda tutabileceği, kapitalist bir yapı teşkil etse bile, bilimsel yöntemlere göre işlev görerek, kamu yararını korumaya hizmet edebileceği (Taş, 2012, s. 79) fikri de beraberinde ileri sürülmektedir. Bu bağın ısrarla kurulmak istenmemesi ya da kurulması halinde medya yayıncılığının özgürlüğü, yansızlığını sağlayabilmesinde "istenmesi" halinde sistemsel bir engel olmadığı, yalnızca bireysel ihlallerle bu yönde sorunlar oluştuğu vurgusunun yapılması, liberal çoğulcu düşüncenin medyasına ilişkin önemli bir soru işareti oluşturmaktadır. Komisyonun hazırladığı kitapta yer alan "Nitelikli Gazeteciler Toplum İçin Neden Gereklidir" başııkı yazı, medyayı profesyonellerin nitelikleri üzerinden değerlendirmenin yolunu açmaktadır. Yazıda medya profesyonellerinin bilgi sağlama ve denetleme görevlerinden söz edilmekte, bu profesyonellerin bir kısmının işlerini bilinçli ve iyi yaparak demokrasiye katkı sağladıkları, diğer yandan bir kısmının ise özensiz davrandıklarından bahsedilmektedir (Komisyon, 2009, s.30). "...Gazetecinin ${ }^{10}$ ve çalıştığı kurumun omuzlarında ağır bir ahlaki ve vicdani yük vardır" (Kovach ve Rosenstiel, 2007, s.191) sözleri de benzer bir düşüncenin ürünüdür. Liberal düşünce anlatısında, sorun sistemde ya da yapıda değil bireydedir ve ihlaller bireyler tarafından gerçekleştirilir. Bu nedenle etik ve ahlaki sorumluluk da bireye ait olmalıdır. Bu nedenle, sorumluluk sahibi davranması gereken kişiler olarak, mesleğin çalışma işleyişinin kurallarını belirleyenler değil de bu kurallara tabi olması gerekenler olarak tartışmasız kabul edilmiştir. Bu nedenle medyayı düzenleyen metinlerin çoğunda "medya sahibine" ilişkin çok az sayıda yaptırım söz konusudur. Bu da aynı bakış açısının izdüşümüdür. Örneğin kendi ülkemizi hatırlayalım, 1938 matbuat kanunu düzenlemesinde yer alan "kötü ün sahibi kişi, gazete çıkaramaz" anlayışı demokratikleştirilme kapsamında 1950 yılındaki basın kanununda yer bulmamışır"11. Liberal basın kuramında medyanın sahiplik ilişkisinin medya üzerindeki etkisi, profesyonellere sağlanan "özerklik" ile aşılmış gösterilmekte, medya sahibi perdenin arkasına itilmektedir. Arada medya sahipliğinden kaynaklanan etik sorunlar ortaya çıktığında örneğin, patronun çıkarı olduğu bir konu ile ilgili olarak yanlı/yanlış haber yapıldığında, bu da "kişisel zaaf ve sorumluluk" ihlali kapsamında ele alınmaktadır.

Medya sahibini "etki ve belirleme" alanı içinde değil, görüntüsü ile oyun dışı alana taşıyan liberal çoğulcu medya- ekonomi başlığı altında medyanın üretim biçimi ile bağı ya da sermayesi üzerinden bir tartışma yürütmez. Bir ticari işletme olarak daha çok gelir kaynakları vurgulanır, burada da karşımıza "reklam"lar çıkmaktadır. Liberal piyasada reklama atfedilen değer, aynen liberal medya kuramında da yer bulur. Bu anlatı argümanlarını aynen benimsemiş olan komisyon kitabında reklama atfedilen değer şu şekildedir: “... Reklamların ürünlerin satışını olumlu

\footnotetext{
${ }^{10}$ Konumuz gereği bu noktada alıntıda sadece habercileri kastetse de biz medya profesyonelleri şeklinde genişletmek niyetli kullanıyoruz.

${ }^{11}$ Bu iki kanun maddesi için bakınız:

https://www.tbmm.gov.tr/tutanaklar/KANUNLAR_KARARLAR/kanuntbmmc018/kanuntbmmc018/kanuntbmmc018 03518.pdf. Erişim Tarihi: 18.09.2019.

https://www.tbmm.gov.tr/tutanaklar/KANUNLAR_KARARLAR/kanuntbmmc033/kanuntbmmc033/kanuntbmmc033 05680.pdf. Erişim Tarihi: 18.09.2019.
} 
etkilediğini, reklamı yapılan ürünlerin satışının arttığını üretimin sürmesinin üretilen ürünlerin satılmasının ülke ekonomisine katkısı olduğunu biliyoruz" (Komisyon, 2009, s. 35). Reklamı toplumsal yapı içinde bu denli gerekli ve önemli bir konuma yükselten bu bakış açısı, medya reklam ilişkisini de bu hâkim anlayışla inşa eder.

Buna göre; medya ve reklam arasındaki bağ şu şekilde işler. Medya reklam ajanslarının hazırladıkları mesajları okurlarına, dinleyicilerine, izleyicilerine iletir (Erdoğan, 2002, s.404). Medya reklam verenlerden aldıkları reklam ücretlerini gelir olarak kullanır. Liberal anlatı, medyanın devletten ve siyasal partilerden bağımsılığının bir nevi garantisi olarak reklamları gösterir, hatta "tarafsız" olarak kendini tanımlayan medya kanallarından Fox TV'nin, sabah haberlerinde uzun soluklu reklam aralarına giderken sunucusunun sloganlaştırmasında olduğu gibi reklam-medya arasında ilişkisi bir anlamda "özgürlük" teminatına da dönüşür. Bu görüşe göre medya, mal ve hizmetlerin serbest ve eşit olarak piyasada rekabet etmesine destek verirken, kendisi de herhangi bir manipülasyona direnebilmesini sağlayacak olan "gelir" gücüne sahip olmaktadır.

Daha çok "olumlu" sonuçlarına göz önünde tutulması salık verilen (Komisyon, 2009, s. 35) reklamların, dikkat edilmesi gereken yanları olarak şunlar tartışmaya katılır: Reklamlarda hukuk, genel ahlak, dürüstlük ve doğruluk (rakipler ve tüketicilere karşısında dürüstlük ve doğruluk) ilkelere uyulmaması, aldatıcı ve yanıltıcı reklamlar, hisleri veya zayıf kişileri istismar edici reklamlar, tüketicinin can ve mal güvenliğini tehlikeye düşürücü reklamlar, kamu sağlığını bozucu reklamlar, reklamların içeriğine ve yayınlanmasına ilişkin olarak da, reklamların yayınlanma biçimi ve sunuluşu ve reklamların yerleştirilmesi ve reklamların yayın süresi (Erdoğan, 2002, s.417). Reklam bu çerçevede serbest pazar içerisinde ve onun pazar dengelerini gözeterek, yararlı ya da zararlı değerlendirilmektedir. Komisyonun kitabında reklam ile ilgili tartışılması gerekli olarak ortaya konulan soru alanları bu bakış açısının ürünüdürler. Hatta kitapta soruları sormadan önce şu ibarenin eklenmesi de soruların olası cevaplarını belirleyici niyet ve niteliktedir:

“...Reklamların bu tür olumlu sonuçları ${ }^{12}$ göz önüne alarak aşağıdaki soruları arkadaşlarınla tartış. Televizyonda reklam programları olmalı mı? Reklam programlarından bilgi edindiğin oldu mu? Reklamlarda gördüğün bir ürünü alıp hayal kırıklığına uğradın mı? Televizyonda reklam programları yayınlanmazsa ne olur?" (Komisyon, 2009, s.35).

Liberal anlatıda; toplumdaki yapılar birbirinden bağımsız işler biçimde figüre edilmiştir. Bu bakış açısıyla medya da bu yapılarla bağı kurulmadan anlatılan bir araç olarak sunulmaktadır. Her bir yapı kendi bağımsız ve özerk alanının içerisinde düzgün bir biçimde işlevlerini yerine getirmesi halinde toplumun "mükemmel" dengesi korunacaktır. Medya da bu çerçevede, siyaset,

12 Vurgu bana aittir. 
ekonomik ve toplumsal yapıdan "bağımsız" bir biçimde konumlanıp, üzerine düşen işlevleri "nesnel, yansız ve tarafsız" bir biçimde sağlarsa toplumsal dengeye katkısını sağlamış olacaktır. Medyanın bu işlevinin denetimi ise, medyanın toplum ve kültür bağlamında ortaya çıkardığı etkileri ölçmek ile sağlanmaktadır. Liberal medya kuramı çerçevesinde yapılan araştırmalar da bu nedenle "etki" sorunsalı üzerine kuruludur. Medyanın etkilerini saptamak, onun toplum dengesinin ve devamlılı̆ının sağlanması konusundaki etkinliğine ve buna bağlı sorumluluğuna ilişkin ipuçları da almaya yaramaktadır. Komisyon kitabında da medyanın bu yöndeki işlevini ortaya seren şu soru göze çarpmaktadır: “...sizce kültürün korunması ve gelecek kuşaklara aktarılmasında medyanın etkisi ne kadardır? Olumsuz etkisinin sonuçları neler olabilir?”.

Liberal medya kuramı bağlamında gerçekleştirilen araştırmalar ile farklı dönemlerde güçlü, sınırlı ve pasif şeklinde farklı medya etkileri tespit edilmiştir. Burada dikkati çeken, medyanın etkisi her dönemde kabul edilmekle birlikte, bireylerin bunlarla baş edebilme biçimleri göz önünde tutularak bir tespitte bulunulmasıdır. Medyanın etkileri aslında bireylerin medyadan etkilenmeleri ile eşitlenmiştir. Elde edilen etki sonuçları, bireyin medya ile kurduğu iletişimdeki "etkinliğini" ortaya sermektedir. Davranış odaklı bu araştırmalarda, bireyler, "dışarıdan gelen bir uyarana tepki geliştiren varlıklar" olarak alınırlar (Taş, 2017, s. 29). Buna göre; bireyler mesajlarla karşılaştıklarında verdikleri tepkilere göre, güçlü ya da pasif olan alıcı birey olarak işaretlenmektedirler. Böylelikle bu vurgu, medyanın sorumlulukları konusunda da belirleyicilik oluşturmaktadır. Medyanın sorumluluğu, mesajlarına maruz kalan birey ile medya mesajlarını isteğine göre kullanan ve kendi hazlarına ulaşan bireye karşı doğal olarak farklı oranlarda biçimlenecektir. Savaş dönemlerinde yapılan bilimsel araştırmalarda medyanın etkileri, kısa dönemli fakat son derece güçlü ve alıcılar ise pasif çıkarken, savaş sonrası dönemlerde yapılan araştırmalarda medyanın birey davranışı üzerindeki etkisinin o denli güçlü olmadığı, bireyin kendi hazları ve arzuları doğrultusunda medya içeriklerini tükettiği yönünde bilgiler ortaya konmuştur. Bu noktada şunu söylemek gereklidir; liberal dünyanın garantilediği alanlardan biri de bilimdir. Bu noktada "sihirli" kelimeler icat edilmiş ve bunlarla bir dünya inşa edilmiştir. Pozitivist bilgi birikiminin gerçekliğe erişme ve onu tanımlamadaki üstünlüğü tam da bunun üzerine kuruludur. Böylelikle yapılan araştırmaların sonuçları tarafsızık, nesnellik, doğruluk ve gerçeklik gibi doğal üstünlüğü olan ve tartışmasız olumlanan kelimeler ile bireyler için zorunlu kabullere dönüştürülmüştür. Sorunun nasıl formüle edilip, araştırmanın nasıl tasarımlandığının, sonucu net bir biçimde etkilediği bu manipülatif alan, her alanda olduğu gibi iletişim alanındaki araştırmaların sorunlarının esas odağını teşkil etmektedir. Kapitalist yapıyı deşifre edici nitelikte bir bulgu araması sistem ile iş birliği nedeniyle imkânsız olan liberal pozitivist bilim dünyası yukarıda da bahsettiğimiz gibi medyanın etkilerine ilişkin birbirinden farklı sonuçlara erişmeyi tutarsızlık olarak görmemekte, aksine her birini ayrı bir "meşrulaştırma" zeminine yerleştirmektedir. Konjonktürel olarak kapitalist sermayenin ihtiyaçlarına cevap vermekle malul olan pozitivist bilim dünyası sermayenin o an itibariyle kar ve maliyetini olumlu etkileyecek sonuç ve çözümler ile doludur. Medyanın etkileri kapitalist pazar payında ona, o momentumda biçilen role göre biçim almaktadır, örneğin bireylerin kültürel deformasyonlarına ilişkin eleştirilerin 


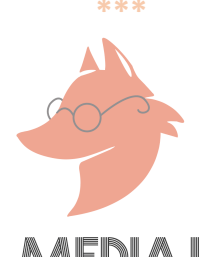

arttığı yıllarda, aktif izleyici tezlerinin bilimsel çalışmalarda bulunmasını iyimser bir tesadüf olarak almak imkânsızdır. Kendi ihtiyaçları doğrultusunda seçimlerini yapan "modern" birey anlayışıyla da uyumlu olarak medyanın onunla ne yaptığından çok, medyayla o ne yapıyor şeklinde bir soruyu temel alarak "aktif" izleyicilere ulaşılmıştır.

Liberal anlatının medyası kapitalist ideoloji ile uyumlu olarak, bireylerin mevcut yaşam ve durumlarını onlar için idealize eder, bireyi de bu "huzurlu" dünyada seçimlerini kendisi yapan, akılcı bireyler olarak betimler. Bu bireylerin medya ile olan ilişkisi de pek çok alanda olduğu gibi bilim dünyasının verdiği onay ile "kullanıcı hatası"na indirgenir. Bu çok bilindik pazar stratejisi ile medyanın insan yaşamlarında daha da fazla yer alması da garantilenmiş olur. Birey yalnızlaştırılma politikaları çerçevesinde daha fazla bir biçimde medya kullanımlarına açık hale gelir, dijitalleştirilen dünyada yaşamını konforlu hale getiriyorum görüntüsü altında savunmasız bırakılır ve ideolojik etki ve yönlendirmelere daha açık hale gelir. Sorgulayıcı ve eleştirel düşünümsellik bir yana gündelik yaşamın içerisinde ihtiyaçlar hiyerarşisinin en basit seviyesinde ilerler, liberal yapının felsefeyi gönderdiği dünyada, medyanın çizdiği kadar bir dünyanın varlığını bilir ve yaşar. Aslında liberal dünyanın bireyi için medya; çok daha güçlü bir etki alanı olarak tasarımlanmış olup, kültürel dünyanın biçimlendirilmesinde aktif role sahiptir. Fakat liberal anlatının medya ve medyaya ilişkin tanımları ve kavramsallaştırmaları bu gerçeklikleri içinde barındırmak bir yana, illüzyon yaratıp bireyin bilincini ters yüz etmektedir.

Medyaya ilişkin diğer yaklaşımlar ise, eleştirel yaklaşımlar olarak bilinmektedir. Eleştirel çalışmalar kendi içinde farklı odak noktaları seçmeleri ile birbirinden farklı alanlara ayrılmaktadır. Bununla beraber bu çalışmalar, kapitalist ekonomik düzene ve liberal sisteme eleştiri yöneltmeleri ile ortak olarak "eleştirel" sıfatı ile nitelendikleri belirtilmektedir (Dursun, 2001: 21). Buradaki "eleştirel olma" ifadesine tekrar dönmek kaydıyla ilkin "eleştirel" çatısı altında ele alınan bu yaklaşımları biraz detaylandıralım.

Eleştirel yaklaşımlar medyaya odaklanırken farklı sorunları merkeze alırlar. Buna göre de iki farklı çizgi ortaya çıktığı belirtilir (Aktaran Dursun 2001, s.21):

1. Medya endüstrilerinin ekonomik örgütlenmeleri ve mülkiyet ilişkileri üzerinde odaklanan çizgi.

2. Medya anlamlarının oluşumu, yapılanması ve tüketiminde odaklanılan çizgi.

Illk yaklaşımda kapitalist ekonomik düzen içerisinde medya içeriklerinin biçimlenişi ve alımlanışına ağırlık verildiği; ikincisinde ise, kapitalist ekonomik düzenin medya örgütlenme yapısının temel alındığı görülmektedir. Bu, görüldüğü üzere, aslında bilinçli bir tercihi kapsamaktadır. Daha evvel de belirttiğimiz üzere, bir yaklaşımda sorulan soru, ortaya konulan sorunsal gerçekliğin temsilinin tespitinde büyük bir belirleyicilik taşımaktadır. Daha soru sorulduğunda aslında kendiliğinden bazı şeyleri kapsamın dışına iterek, bir ideolojik perdeleme 
sağlanmış olmaktadır. Daha açık bir deyişle, soru aynı zamanda bir önem alanı oluşturmaktadır. Bu nedenle de dışarıda bırakılan kısım da sorunun cevap alanı için mutlak bir eksiklik olarak karşımıza çıkmaktadır. Bu nedenle yukarıdaki kuramsal yaklaşımların ikisi de aslında bir bütünün ikiye bölünmüş olması nedeniyle yapısal bir eksik bırakılmışlığa sahiptir.

Kendi içinde bölünmüş olmanın verdiği zayıflıklara rağmen, eleştirel yaklaşımlar medyanın gerçeklik ile bağına ilişkin ortaya koyduğu argümanlar ile liberal anlatının inşa ettiği zihinsel dünyanın sorgulanmasını zorlamaktadır. Örneğin; Medya endüstrilerinin ekonomik örgütlenmelerine ve mülkiyet ilişkilerine odaklanan klasik Marksist anlayışlarda; medyanın toplumsal gerçekliği kapitalist sınıfın çıkarları doğrultusunda çarpıttığı ve bozduğu ifade edilmektedir. Buna göre;

“...Toplumsal gerçeklik aslında çok temel bir çelişki tarafından oluşturulmaktadır: Üretim araçlarının özel mülkiyetine sahip sermaye sınıfı, toplumsal olarak üretilen artı değere el koymaktadır. Toplumsal failler olan insanların bu temel çelişkiyi görebilmesi ve gerçek durumlarını kavrayabilmesi Marksist toplumsal eleştirilerin temel derdidir. Çünkü ancak bunun fark edilmesiyle sınıfsal mücadelenin devrimci bir dönüşümle sonuçlanma ihtimali belirir. Kapitalist ideoloji tam da bu çelişki çevresinde yapılanan her türlü toplumsal ilişki türünde sömürücü, tahakkümcü, baskıcı ve özgürleşim karşıtı bir yön olduğunun gizlenmesini sağlamaktadır. Bu noktada modern kitle iletişim araçlarına düşen görevler, çelişkinin fark ettirilmemesi, toplumsal iktidarın bütün biçimlerinin aslında üretim ilişkilerine hükmetmekten gelen ekonomik iktidara bağlı olduğunun gözden kaçırılması, insanların mevcut üretim ilişkilerini sürdürecek toplumsal ilişkilere rıza göstermesinin sağlanmasıdır. Medyanın bunu yapabilmesi için, tahakküm ilişkilerini pekiştirecek ve doğallaştıracak anlamları dolaşımda tutması, alternatif anlamları ise dolaşıma sokmaması gerekmektedir. Böylelikle egemenlik ilişkilerinin üretimi ve yeniden üretimi, ideolojik ve kültürel anlam sistemlerinin üretimiyle bağlantılanır. Bunları sağladığı ölçüde medya, ideolojik işlevlerini yerine getirmektedir" (Dursun, 2013, s. 39-40).

Burada görüldüğü üzere liberal anlatı dünyasının ortaya koyduğundan farklı olarak "negatif" bir medya kavramsallaştırması söz konusudur. Gerçeği olduğu gibi yansıtan ayna rolünde, bağımsız, tarafsız ve nesnel bir medya yapılanmasının olabilirliği ve toplumsal gelişmeye katkısı olan bir medya anlatısının aksine, toplumsal üretim ilişkilerinden kaynaklanan eşitsizliğin içinde oluşan ve bu çarpık yapının devamlıı̆ı̆ı için bireylerin hem bu ilişkileri normalleştirmesini sağlayan hem de onları değiştirme potansiyeli olan anlamların üretilmesini engelleyen medya anlatısı söz konusudur.

Liberal anlatıda toplum yapısı sınıflı ve onların çatışmaları üzerine kurulu değildir, aksine toplum birbirinden farklı rollere sahip bireylerin oluşturduğu bir organizma şeklinde tasarımlanmıştır. 


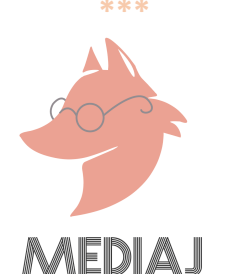

Buradaki bireyler akılcı ve eşittir, üzerlerine düşen görevi layığı ile yerine getirdikleri sürece toplum mükemmel uyum ve dengesi içinde devam eder, toplumdaki eşitsizliğin oluşması yapı ya da sistem sorunu olarak değil, bireysel başarısızlıkla açıklanır. Burada değişime açık bir toplum yapısından ziyade tutucu korumacı bir anlayış vardır. Daha açık bir deyişle, toplumun mevcut yapısını oluşturan üretim ilişkileri tartışmaya açık olmayacak bir biçimde muhafaza edilmeye gayret edilir, sorgulanmaya kapalı olan yapı ancak tadilatlara açıktır. Medya da bu yapılanma içerisinde mevcut yapının dengesinde kendisine önemli bir kamusal görev verilmiş bir aygıt olarak işler. Oysa Klasik Marksist yaklaşım tamamen sistemin eşitsizlik üreten yapısını hedef alır ve deşifre eder; bunun değiştirilmesi gereğini öngörür. Liberal anlatıya karşıt olarak toplumdaki sınıflı yapıya işaret eder, toplumdaki bireyleri sömürücü sınıf tarafından bilinci kuşatılmış edilgen bireyler olarak konumlandırır, toplumsal gerçekliği bireylerin sisteme direngenliğini sağlayacak biçimde alt üst eder. Medya da bu sistem içerisinde sistemi birey için doğal, kaçınılmaz bir unsur olarak nakşetme ve sisteme direnme yollarını tıkama, böylelikle mevcut sistemin devamını hatta güçlenmesini sağlayan bir aygıt olarak konumlanmıştır. Burada şunu vurgulamak gerekmektedir. Medya mevcut üretim ilişkilerinden etkilenen bir yapı değildir; bizatihi içinde bulunduğu üretim yapısının doğal uzantısı olarak vardır, bu nedenle de hem epistemolojik hem de ontolojik olarak sistem ve onun çıkarları ile özdeşleşmiş bir yapıya sahiptir. Bu nedenle özellikle günümüzde kapitalist yapı ve onun eşitsizlikçi yapı, işleyiş ve anlayışı medya örgütlenmesinde de hâkimdir. Artı değere el koyma prensibiyle eşitsiz ve adaletsiz işleyişe sahip medya örgütlenmesinin bu yapısı hem örgütün iç işleyişine hem de içeriklerle zihinlerde kurduğu anlamlara sinmiştir. Medya örgütlenmesi gelir adaletsizliği ve sendikasızlık ile karakterizedir. Bu işçilerin üretimi de bu şekilde kısıtlanmış; ürettikleri ürünler de bu anlam zayilikleri ile maluldür. Daha açık deyişle, bu üretim yapısı ve işleyişinin içinde boyun sunmuş, özgürlüğünü elinde tutmayan fikir işçilerinin sistemin çıkar ve arzuları dışında bir içerik üretme bilinçliliğine sahip olmamaları da gerek eğitim gerekse maddi baskılama yolu ile garantilenmiştir. Bu nedenle, neoliberal piyasanın fikir iş̧̧ileri, işini kaybetme endişesi, gelirinin azalması korkusu, bazı konforlarını yitirmeyi istememesi gibi yaratılmış endişelerini iç sansüre dönüştürmüş, piyasadaki kuralları ve işleyişi doğallaştırmış, Marksist anlayışın toplumsal çelişkiyi çözüp değiştirme ideali, yerini "ayın çalışanı" olma idealine terk etmiştir. Bu nedenle de sistemin devamını sağlayan ve sağlayıcı içeriklerin üretimi sektörde hâkim kılınmıştır.

Eleştirel yaklaşımların medya anlamlarının oluşumu, yapılanması ve tüketiminde odaklanılan çizgi şeklinde tarif edilen diğer yaklaşımda ise, medyanın toplumsal gerçekliği inşa ettiği ifade edilir. Buna göre;

“...toplumsal bilginin inşasının hem medya hem de izleyici /okur kitleleri tarafından birlikte gerçekleştirilen bir süreç olduğu vurgulanır. Toplumsal bilgiyi inşa ederken medya, belirli anlamları ve yorumları tercih eder, bunlara dayalı sınıflandırma ve düzenlemeler ile belirli gerçeklikler içerilir, diğerleri dışta bırakılır. Medya, paylaşılan bir toplumsal fenomeni tanımlamasıyla birlikte, aynı 


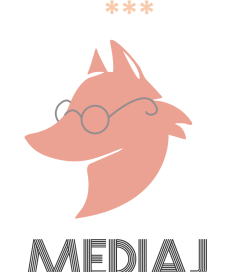

zamanda onun oluşturulmasına da yol açmaktadır. Medyanın tanımlamaları, adlandırmaları, sınıflamaları, kurduğu neden- sonuç ilişkileri, toplumsal alana, sıradan insanların günlük dünyasına geçer ve yayılır. Insanlar kendi öznel dünyalarını ve elbette kimliklerini de medyanın inşa ettiği sembolik gerçekliğin sunduğu başvuru çerçevelerine göre kurarlar. Medyada karşısına çıkan gerçeklikle toplum bir ilişkiye girer. Haberler, diziler, filmler, yarışma ve eğlence programları, belgeseller, haber, magazin ve hobi dergileri, gazeteler, insanlara içinde yaşadığı gerçekliğin değerlerini, değerlere yönelik tehditleri, normal ve anormal arasındaki ayrımı, kabul edilebilir olan ve olmayan hareketler arasındaki sınıları, gücün değiş- tokuş tarzlarını göstermektedir. Esasında bu gösterimi toplum kendisine yapmaktadır; toplum ne olduğunu medya yoluyla bilmektedir. Toplum/toplumsal içinde insanlar, medya içeriklerinde karşılaştıklarıyla gerçekleştirdiği özdeşlikler ve yadsımalarla kendisini tutarlı bir bütünlüğün parçası kılmaktadırlar. Medyanın gerçekliği inşa ettiği görüşü özellikle ideoloji eleştirisinin klasik "çarpıtılmış bilgi" konusuna odaklanmanın zayıflamasıyla birlikte, Marksist eleştirel toplum ve medya kuramlarında da dikkate alınmaya başlanmıştır. Elbette Marksist eleştirellik içerisine medyanın gerçekliği inşa ettiği önermesi bu inşa daha çok verili güç ilişkileri ve sınıf mücadelesi dinamikleriyle bir biçimde bağlantılı kılınarak dahil edilmektedir" (Dursun, 2013, s. 40).

Kültürel çalışmalar olarak da nitelenen bu kuramsal bakış açısı, "eleştirel” olma sıfatını kapitalist üretim tarzının kurduğu güç ve iktidar ilişkilerine odaklanmakla hak eder. Bununla birlikte, klasik Marksistlerden farklı olarak alt yapı üst yapıyı belirler önermesinin katılığını yumuşatır ve üst yapının alt yapının belirleyiciliğine olan esaretini gözden geçirir. Bunu da üretim yapı ve işleyişine odaklanmak yerine anlamlarının oluşumu, yapılanması ve tüketiminde odaklanılan çizgiye eğilerek, klasik Marksistlerin odaklarını farklı noktaya, kaydırarak sağlar. Klasik Marksistlerin güç ve iktidar çözümlemelerinde değişip dönüştürülmesi için şart gördükleri üretim biçim ve işleyişinin yerine, anlam üretim ve işleyiş süreçleri ve oradaki güç ve iktidarın deşifresini, öne çıkarılmasını da sistemin dönüşümü için bir olasılık haline getirirler. Buradaki iddianın ardında biraz da Marksizmin çarpıtılmış gerçeklik ile yanlış bilinçlenmiş bireyinin bu yapıları çözüp, dönüştürme potansiyelinin de düşüklüğü ve imkân dışılığına olan itirazın bulunduğu düşünülmektedir. Çünkü klasik Marksizmde egemen görüşün hâkimiyeti mutlaktır, direngen ve muhalif alanların varlığının yaşamı sınırlıdır, çözüm ancak bilinçlenmesi sağlanan işçilerin sistemi tamamen değiştirmek üzere eylemine odaklanır. Kültürel çalışmalar, bireyin bu denli belirlenmiş olduğu bu anlatı yapısının toplumdaki muhalefet odaklarını ve potansiyellerini açıklayabilme konusundaki zayıflığına karşı bir açıklama getirmesi ve klasik Marksizmin aslında sömürülen ve sömüren ilişkisindeki "dar" çerçeveyi genişletip, güç ve iktidar odaklarının işleyişlerini tartışmaya açarak, bunlara ilişkin muhalefet etme biçimlerini de genişletmesi ile önemi yadsınamaz bir tartışma alanını aralamıştır. Kültürel çalışmaların, toplumsal gerçekliğin çarpıtıldığı fikrine karşıt, gerçeğin inşa edildiği argümanının olması da klasik Marksist anlayışın kuşatılmış birey fikrinin tekrar düşünülmesini zorunlu hale getirmiştir. Gerçekliğin olduğu gibi sunulduğu ya da gerçekliğin asla yansıtılmadığı iki düşüncenin karşısına bir ara yol olarak dikilen kültürel 
çalışmalar, gerçekliği bir mücadele alanına dönüştürerek, "katı" bir tespiti reddetmektedir. Çünkü gerçekliğin hiçbir çıkara bağlı kalmaksızın nesnel bir biçimde sunulabileceği iyimserliği ve gerçekliğin tamamen bozulduğu ve asla gerçekliğin egemen çıkarlar dışında üretilemeyeceği kötümserliği de tutucudur. Buna karşılık üçüncü bir yol olarak kültürelci bakış açısı, gerçekliğin bir mücadele ile belirlendiği ve bu mücadelede de klasik Marksistlerin iddia ettiği gibi illaki egemenin galebe çalmasının söz konu olmadığı iddiası ile tartışmaları başka bir boyuta taşımaktadır. Bu tartışmaları medya ayağı ile birleştirdiğinizde, iki sonuç ortaya çıkmaktadır: illki, kültürel çalışmalar medyanın kapitalist bir üretim biçiminde olduğunu bilir fakat bu gerçekliği bu yapının üzerinde bir belirleyicilik alanı olarak ele almaz, bu da bir "özerklik" alanı tartışmasını aralar. Güç ve iktidar ilişkilerinin anlamsal dünyada şiddetlendiği ve yapısal şifrelerinin kırılması ile eşitsizliklerin giderilebileceği inancı, medyayı ve buna bağlı olarak medya profesyonellerine bakışı da farklı konumlandırır. Şöyle ki, klasik Marksist anlayışta yer alan üretim biçimi ve buna ilişkin medya rolleri belirlenmiş medya profesyonellerinin sistem çıkarlarının dışında bir bilince sahip olmadığı/olmasını engellediği önermesi, onları, "etik" alanın dışına iterek sorumluluktan muaf bir birey kılarken; kültürel çalışmalar, üretim biçiminin mutlak egemenliğini sarsmış ve medya profesyonellerine direngen bir nefes alanının mümkün olabileceği fikrini hediye etmiştir. Böylelikle de klasik Marksist görüşün tamamen kuşatılmış medya ve medya profesyonelleri anlayışı, yerini sürekli kazanılması gereken "mutlak" hâkimiyetlerin olmadığı ve direnç gösterebilen bireylerin olduğu alanlara bırakır. Burada Gramsci'nin "hegemonya" ve "karşıt hegemonya" kavramlarını ve Foucault'un güç, disiplin ve direnç ile ilgili görüşlerini hatırlamakta yarar vardır (Şahin, 2011, s. 25, 28). Her iki entelektüel de güç odaklarını tanımlamışlar ve pratiklerine işaret etmişler fakat klasik Marksistlerden farklı olarak bunlara direnme olanaklıığı ve biçimlerinden daha vurgulu bir şekilde bahsetmişlerdir. Bu noktada medyaya biçilen rolü özetleyecek olursak; medya da diğer başka kurumlar gibi toplum üzerinde bir kontrol gücüne sahiptir, fakat medyanın bu gücü bir kaba güç şeklinde işletilmez, hegemonik (örtük ve rızaya dayalı) bir biçimde işler. Kapitalist toplumlarda egemen yapı güce ve zorlamaya dayalı kontrol yerine, rızaya dayalı bir sömürü amaçlar. Bununla beraber medyanın hegemonya aracı olarak işlevinin anlaşıması, "sağduyu" veya "normal" olarak algıladığımız sinsice durumlara karşı sorgulayıcı bir bakış açısı geliştirilmesi ve karşıt hegemonya aracı olarak medyanın rolünün kavranabilmesi halinde egemen yapıyı değiştirecek ve dönüşebilecek bir medyadan da bahsedilmektedir (Şahin, 2011, s.25-26). Toplumsal gerçekliğin inşa edildiği görüşünün hâkim olduğu bu yaklaşımda, medyanın bir toplumsal fenomeni tanımlayarak, onun oluşturulmasına yol açtığı bireylerin de bu medya içeriklerinde karşılaştıklarıyla gerçekleştirdiği özdeşlikler ve yadsımalarla, kendisini tutarlı bir bütünlüğün parçası kıldığı ifade edilmektedir (Dursun, 2013, s. 40). Medyanın içeriklerinin anlam kapalılı̆ı̆ı reddeden bu bakış açısı, bireyin okuma ve anlamlandırma süreçlerine değer atfederek, "aktif izleyici" modelinin bir üst sürümüne ulaşmıştır. Bir bakıma metnin artık hangi ekonomik ve sosyal bağlamda üretildiği gerçeğini ıskartaya çıkaran bu anlayış, bütün odağını tüketilme anına ve üretilen /üretilemeyen direngenliğe kaydırmıştır. Bu yaklaşımları İran Erdoğan ve Korkmaz Alemdar, 


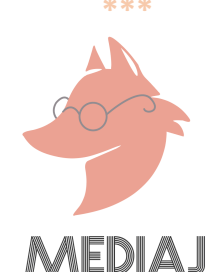

“...kişilerin 'siyasal olarak özgürleşen metinlerden' ve 'karşıt okumalardan' geçerek kişisel kimlikler kurması ve televizyon durum komedilerinden ve dizilerden geçerek kapitalizme karşıtlık oluşturması, Garnham'ın da haklı olarak belirttiği gibi apaçık saçmalıktır. İnsan, metinlerle ve metinlerden geçerek yaşamıyor. Metinlerle ve metinlerden geçerek karın doyuranlar ve karşıtık üretenler için bu belli ölçüde doğru olabilir. Metni anlama ve anlamlandırma belli örgütlü yer ve zamanda egemenlik ve mücadele ilişkileri ve fiziksel ve sosyal olarak varlığını sürdürebilme koşullarıyla bağlam kurmayı gerektirir" (2010, s. 365).

sözleriyle eleştirmişler ve toplumsal değişimin metinlerdeki anlamlar üzerinden verilecek olası bir mücadele ile elde edilemeyeceğine şu cümlelerle işaret etmişlerdir:

"...toplum statik bir metin değildir, sayısız ve bağımsız "metinlerden" ve "diskorslardan" da oluşmaz. Toplum değişimi metindeki temsillerden ve televizyon önünde anlam vererek veya internette anlam alışverişi yaparak olmamıştır ve olmaz da. Toplum değişimini gerçeği belirleyen dil de yapmaz. Toplum değişimini tarih boyu düşünceleri taşıyan ve dili kullanan insanlar değişim için gerekli somut insan girişimleriyle yapmıştır" (2010, s.366).

Alıntıdaki bu eleştiriler, bir kavramın eleştirel sıfatına sahip olmasının onun gerçek anlamda eleştirileri içinde barındırıp barındırmadığının garantisi görülemeyeceği yönündeki tespitimizi yeniden düşündürmektedir. "Eleştiri" kelimesi sözlükte "bir insanı, bir eseri, bir konuyu doğru ve yanlış yanlarını bulup göstermek amacıyla inceleme işi, tenkit"13 olarak tanımlanmaktadır. Oldukça dar ve felsefi yanı hiç geliştirilmemiş bir seviyeyi işaretleyen bu tanımın üzerinden dahi gidilse, bugün pek çok "eleştirel" durumun eleştiri kabul edilemeyeceği muhakkaktır. Yine de tanımdan ilerleyecek olursak, burada "eleştiri" kelimesi herhangi bir şeyi neden/sonuçları ile ele alarak gerekmesi halinde değiştirilmesi ya da dönüştürülmesi yönünde bir amaç /niyet sahibi olarak donanmamakta, daha çok mevcut halin devamlılı̆ı için iyileştirici tadilatlar şeklinde kısıtlanmaktadır. Daha açık bir deyişle, eleştiri ya da eleştirel olma hali bir yapıyı yerinden sökücü bir nitelikte olmaktan ziyade, mevcudu uyumlaştıııcı olma ile öne çıkmaktadır. Buradaki liberal duruş dikkat çekicidir. Liberal anlayışta hâkim olan organizmaların kendi içinde uyumlu ve ahenkli çalışmanın muhteşem denge olarak ortaya konması ve sistemin içerisindeki aksaklıkların "bireysel" seviyede ele alınması anlayışı ile "bunları ortaya koyacak incitici olmayan tadilatçı eleştiri" sistemin ana çalışma düzeneğini sorgulamayan, yalnızca onu iyileştirip daha etkin olmasını sağlayan yönüyle uyumlu gözükmektedir. Bu nedenle de yukarıda kültürel çalışmalara ilişkin klasik Marksistlerin ortaya koyduğu görüşler, ciddi nitelikte olduğu kadarıyla, eleştiri kavramını da gözden geçirme gerekliliğine işaret etmesiyle anlamlıdır. Bir kavram ya da bir yaklaşıma eleştirel sıfatı vermek için onun sistem ile yapı ile ilişkisine bakılmalıdır. Sistem ile

13 İnternet Erişim Adresi: https://sozluk.gov.tr/ Erişim Tarihi: 07.09.2020. 


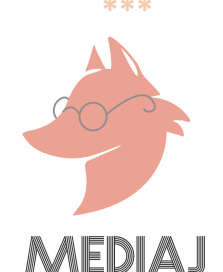

entegre organik bağa sahip olan kimi görüşlerin zaman zaman sistemin içinde ılımlı muhalefet rolünü üstlendikleri, böylelikle hem sistemin içindeki muhalefet odaklarının enerjisini boşalttıkları, hem de sistemi "demokratik" bir yapı görüntüsünde tuttukları görülmektedir. Kültürel çalışmaların "eleştirelliğine", medyaya ilişkin yaklaşımıyla kapitalist üretim yapısını odak noktasından kaydırıp, anlam ve okur ağırlıklı bir güç iktidar deşifresine girişmesiyle, sistemin içerisinde ne denli bir oyuk oluşturduğuna bakarak inanmak gerekmektedir. Yaklaşımın önemli sorunları gündeme getirdiği muhakkaktır, bununla beraber sunduğu çözümlerin sistemi değiştirme ve dönüştürme potansiyeli tartışmalıdır.

Buraya kadar ifade ettiklerimiz, mevcut medya okuryazarlığı kavramını anlamak ve alternatif bir tanım için gerekli olan bilgi birikimine işaret edebilmek içindi. Medyaya ilişkin hâkim bakış açısı, medya okuryazarlığı kavramını doğrudan etkilemektedir. Başta da ifade ettiğimiz gibi, medya okuryazarlığı tamlamasında medya önemlidir; medya nasıl bir içerik ile doldurulmuşsa, ona ilişkin planlanan okuryazarlık da onunla sınırlı olacaktır. Mevcut medya okuryazarlığı anlayışına bakıldığında, liberal medya anlayışının mutlak hâkimiyeti görülmektedir. Hatta "eleştirel "medya okuryazarlığı olarak sunulan yaklaşımların da çoğu, eleştirel olmaktan uzak yapılandırılmıştır. Bu noktada medya okuryazarlığına ilişkin tanımlara bakmak faydalı olacaktır.

\section{Medya Okuryazarlığı Kavramı}

Medya okuryazarlığı temel olarak çeşitli biçimlerde mesajlara ulaşma, analiz etme, değerlendirme ve iletme yeteneğidir (Koltay, 2011, s.212). Medya okuryazarı; medyada yeniden kurgulanan iletileri ayırt edebilen ve algılayabilen, onunla ilgili yorumlarda bulunabilmek için ayrı bir beceri, altyapı bilgisi ve eğitsel organizasyon gerektiren bir eğitim sürecinin sonucu olarak medya yetkini sıfatını hak eden kişiyi betimleyen bir terim olarak algılanabilir (Öncel, 2007, s.7).

Yukarıdaki tanımlarda görüldüğüü üzere, medya okuryazarlığı kavramı mesaj odaklıdır. Daha açık bir deyişle, medyanın nasıl üretildiği ve nasıl bir üretim yapı ve ilişkilerine ait olduğundan ziyade medyanın ürettiği ürün üzerine ve onun tüketimine yönelik bir bakış ağılıklıdır. Tanımda bireyin medya okuryazarlığı becerisi kazanımı ile birlikte elde edeceği yetilerden biri, erişimdir. Medya mesajlarına bireyin erişimi basit bir piyasa arzusunu hatırlatmaktadır. Burada iki yarar, sağlanması muhtemel hedeftir. Bireyin medyaya erişim yollarını bilmesi, medyayı daha etkin ve yoğun kullanımını garantileyecektir; bununla beraber "medya okuryazarı" ehliyeti ile erişmesi birey üzerinde sakıncalı olan etkileri de bertaraf edecek, medyanın bireyin hayatını günden güne giderek kaplıyor olmasına yönelik sosyolojik ve psikolojik bir endişeye zemin vermeyecektir. Tanımlarda "analiz etme, değerlendirme ya da kurgulanan iletileri ayırt etme yetilerinin kazandırılacağı ifadeleri de bu düşünceyi güçlendirici cümlelerdir. Böylelikle bireyin, medya okuryazarlığı eğitimi çerçevesinde kazanacağı ifade edilen analiz etme sorgulama yetileri ile karşılaştığı mesaj bombardımanıyla baş edebilir hale geleceği ifade edilmektedir. Burayı açacak olursak, ilkin bireyin sağlıklı bir analiz gerçekleştirebilmesi için neye sahip olması gerektiğine 
odaklanmalıyız. Çünkü her birey için, her koşulun aynı olduğunu kabul etmek, iyimserlik ötesi bir ideolojik yanılsamadır. Bireyin sosyo-ekonomik yapılanması onun zihinsel haritalanmasında etkin olur ve aldığı bütün mesajları da bu bağlamda çözümler. Yani, mesajlara maruz kalması da direnebilmesi de bununla doğrudan ilgilidir. Bu nedenle sırf medya okuryazarlığı eğitimi ile bunu sağlayabileceğine inanmak liberal anlatının bireye oluşturduğu bir illüzyondur. Bireyin koşullarının önemli belirleyicilerinden biri olan "eğitim"in de bunu destekleyici bir ideolojik yapıyla biçimlendirilmiş olması gerekir. Freire'ın (2016) görüşlerinde belirttiği eleştirel düşünceyi körelten bankacı eğitim bakışının hâkim olduğu eğitim sisteminin içine yerleştirilmiş medya okuryazarlığı derslerinin, eleştirel düşünümselliğe değer veren analiz ve sorgulamayı hedeflemesi doğuştan imkânsız bir hale dönüşmektedir. Bireyleri sistemin işleyişine sorgusuz sualsiz tabi etmeye çalışan egemen ideolojinin, "eleştiri", "analiz etme" ve "sorgulama" gibi kavramlara sistemi sorgulayıcı ve dönüştürücü bir içerik yüklenmesine izin vermesi, kendi içinde büyük bir tutarsızlık ve anlamsızlık oluşturur. Bu nedenle yukarıda tartıştığımız üzere bu kavrama eklenmiş bu analiz ve sorgulama yetileri sistemin değil, sistemin ürettiklerinin üzerinedir. Yani, basit bir biçimde üretim hatalı ürünleredir. Bu da pazarda oldukça istenen bir destektir. Ne kadar ürünün kalitesi ile ilgili geri bildirim alınırsa, satışın artırılması garantilenir.

Medya okuryazarlığının diğer tanımlamalarının ilkinde, yukarıdakilerden farklı olarak, "medya okuryazarı, basılı ve elektronik medyayı çözmek, değerlendirmek, analiz etmek ve üretmek yetilerine sahiptir" (Aufderheide, 1992) denilirken, diğerinde, medya okuryazarlığı, medyaya ulaşabilme yeteneği, medyanın ve medya içeriğinin farklı taraflarını anlamak ve değerlendirmek ve farklı bağlamlarda iletişimler yaratmaktır ${ }^{14}$ denilmektedir.

Yukarıdaki ilk tanımlardan farklı olarak bunlarda, aslında sisteme yöneltilen önemli eleştirilerden birinin önünü kesen ifadeler bulunmaktadır. Liberal medya sisteminde izleyicinin pasifliğinin önemli bir eleştiri oluşturduğundan ve sistemin zaman zaman bunlara yönelik genellikle de "post" önekleri ekleyerek, aslında olanı başka türlü göstermeden öteye gitmeyen ideolojik dokunuşlarda bulunduğundan bahsetmiştik. Burada da benzer bir taktiğin izlerini sürmek mümkündür. Medyanın birey yaşamındaki anlamlandırma sürecinde neredeyse tek belirleyici gibi işlev gördüğünün olumsuz yorumlanmasına set çekecek bir kavram olarak icat edilen medya okuryazarlığı, bireyin pasifliğine son kertede çare olamayacağı düşüncesiyle, bir üst sürümle pazarlanmıştır. Daha açık bir deyişle, medya okuryazarının sadece bilinçli bir tüketici olmayacağı, aynı zamanda içeriğini kendi üreteceği ifade edilmiş, tanımlarda bu durum ön plana çıkarılarak, kavram bir başka noktaya taşınmıştır. Oysaki bunun gerçekte hayata ne olasılıkla ve ne kadarının geçirilebilirliği önemlidir. Liberal medya anlatısı ve o düşünce ile biçimlenmiş medya okuryazarlığı kavramındaki birey, serbesttir; pazarda yer alması için önünde engelleri yoktur; burada da bu bakışın izdüşümü vardır. Bireyin içerik üretebilmesi için önündeki tek engel

\footnotetext{
${ }^{14}$ Brüksel Deklarasyonu: http:// www. declarationdebruxelles. be/en/ declaration_accueil.php. Internet Erişim Tarihi: 28.01.2013.
} 
kendisidir. Gerçekte bir içeriğin üretimi ve yaygınlaştırılması bu şekilde kolay işlememektedir. İlkin bir donanıma sahip olunması zorunludur ve bu, bir maliyettir. Bunun tek bir kalemde hallolduğunu düşünelim; bu sefer de internet ücretlerinin sürekliliği için bir gelir sahibi olunması, ön koşula dönüşmektedir. Bunun sağlanması internette ürettiğiniz içeriği paylaşma ve yaygınlaştırma için bir yer edinmeyi ya da mevcut bir alanın kullanılması için bir ücretlendirmeyi gerekli kılmaktadır. Yani bir içeriği üretmek belli bir ekonomiyi de zorunlu kılmaktadır. Girişim bir şekilde temin edilse de bu defa da kalıcı olmak için ya da bu üreticiliğin birey yaşamında "gelir"e dönüşebilmesi için, içeriğinize reklam çekmeniz koşul olarak karşınıza çıkacaktır ki, bu da şu sorunu oluşturacaktır: İçeriğinizin, reklam alabilmesi için, reklamcıların reklam vereceği bir malzeme olarak biçimlendirilmesi gerekecektir. Diğer bir deyişle, özgün, farklı bir içerikten ziyade, daha önceden reklamcı desteğini kazanmış, ekonomik aritmetiği sağlam ürünler tercih edeceksinizdir. Bu da birbirine benzer, standart içerik üretimlerine yol açacaktır. Özetle, medya okuryazarlığı proje ve dersleri ile bireyin içerik "üretici"sine dönüştürülebileceği düşüncesi, yazılım endüstrisini ve onun içindeki oligopol yapıyı hiç hesaba katmayan, gerçek dışı bir yaklaşımdır. Bireyin ise bu güç iktidar ilişkisinde nasıl ayakta durabileceği önemli bir soru ve sorun olarak karşımıza çıkmaktadır. Örneğin; Huawei'n pazarda karşılaştığı engeller ${ }^{15}$ göz önüne alındığında, bu sorunun "kişi" düzeyindeki yansıması oldukça ilginç bir hale bürünmektedir. Liberal medya okuryazarlığı anlatısının bireyin içerik üretme yetisine sahip olacağı vurgusu, pazarın demokratik görünmesine ve bireylerin de üretiyormuş hissederek sisteme daha fazla adapte olmalarının sağlanması amacı taşımaktadır.

Patrica Aufderheide'ın yukarıdaki tanımındaki "medya okuryazarı, basılı ve elektronik medyayı çözer" ifadesine odaklanırsak; cümlenin bu haliyle neyi kastettiği bulanıktır. Buna karşın Aufderheide'ın medyaya ilişkin görüşleri ve medya okuryazarlığına ilişkin sekiz ilkesine göz gezdirirsek, tanımdaki ifadeleri daha düzgün yorumlama imkânı bulabiliriz. Aufderheide'e göre; medya bireylere dünyayı olduğu gibi vermemektedir. Medya gerçekliği yorumlamakta, ona şekil vermekte ve onu temsil etmektedir. Bunun farkına varabilen sorumluluk sahibi bireyler olabilmek için ise medya okuryazarlığına intiyaç duyulmaktadır. Aufderheide, bu amaç doğrultusunda kullanılacak sekiz ilke paylaşmaktadır (Aktaran Alagözlü, 2013, s. 13-14):

1. Tüm medya kurgusaldır.

2. Medya, gerçekliği kurgular.

3. İzleyiciler, medyanın anlamını tartışır.

4. Medyanın ticari faaliyetleri vardır.

5. Medya, ideoloji ve değerli mesajları içerir.

6. Medyanın toplumsal ve politik söylemleri vardır.

7. Medyada biçim ve içerik yakından ilişkilidir.

8. Her medya kuruluşunun kendine has estetik bir biçimi vardır.

15 https:// www. bbc. com /turkce / haberler-dunya-48331068. Erişim Tarihi: 05.10.2020. 
Aufderheide'ın ortaya koyduğu bu ilkeler "Ilımlı" eleştirel bir duruştan ibarettir. Örneğin, "medyanın ticari faaliyetleri vardır" başlığı altında söyledikleri şu sözler buna oldukça iyi bir örnektir:

"Birçok medya ürünü bir iştir ve kar etmek zorundadır. Bu yüzden medyayı çözümlerken şu sorular sorulmalıdır: Bunun için kim ödeme yapmıştır? Bu işi destekleyen ekonomik yapı nedir? Yapımcı, yazar ve yönetmen konu seçip çekime başladığında mali baskı seçimlerini nasıl etkilemiştir? Medya bireylere değil, kitlelere hitap etmektedir. Gençler, kadınlar, erkekler, belirli bir görüşe sahip bireyler kitlelere örnek teşkil etmektedirler. Kitlelerin değeri o kitle için medya tarafından harcanan para ile doğru orantılıdır. Medyanın ticari faaliyetleri bir başka yönden de sahiplikle ilintilidir. Bir şirket, kitle iletişim alanında üretim, dağıtım ve basım gibi birden farklı alanda faaliyetlerini sürdürüyorsa, o şirket üretileni, dağıtılanı ve izlenileni denetim altında tutmak gibi bir beceriye sahip demektir" (Aktaran Alagözlü, 2013, s.13-14).

Yazar, görüldüğü gibi, medya okuryazarlığı ilkelerini ortaya koyarken, medya ürünlerini bütüncül bir biçimde kapitalist üretim yapısının parçası olarak ele almamakta, böylelikle medya ile kapitalist pazar arasındaki ilişkiyi bulanıklaştırmaktadır. Metinde, medyanın ticari yanına değinmek bir farkındalık gibi sunulmakta, oysa medya pazar ilişkisinin girift halinden aslında olduğundan uzak bir biçimde ilişkilendirilerek, medyanın kapitalist yapı ile olan organik ilişkisini düşündürmemektedir. Aslında yukarıdaki bu ifadeler liberal anlatının zaman zaman kamu aracı olan medyanın, çıkarlarını ön plana alıp ticarileşmesi ve ticareti de "vahşi"leştirip, oligopolleşmesi ya da tekelleşmesi anlatısı ile paralellik arz etmektedir. Bu eleştiri sadece, kamusal bir araç olduğu ifade edilen medyanın, kişi ve grupların çıkarları doğrultusunda bireylere ve toplumlara faydalı olmayan faaliyetler yürütmesi üzerine kuruludur. Bu nedenle, yukarıda bahsettiğimiz üzere, bu eleştiriler ıımlıdır ve bu yönde biçimlendirilecek okuryazarlıklar da sistem açısından sorun teşkil edici nitelikte asla olmayacaktır.

Yine bir başka medya okuryazarlığı kavramsallaştırmasında, medya okuryazarlığının sınırlarını oldukça dar tutan şu ifadelerle karşılaşıyoruz: "Medya okuryazarı olmak;

- Medyayı akıllı ve etkili bir biçimde kullanmaktır.

- Medya endüstrilerinin siyasi görüşü, gelişmesi, ekonomik tabanı ve idari yapısı konusunda bilgi sahibi olmaktır.

- Farklı kaynaklardan gelen bilginin doğruluğunu değerlendirmektir.

- Medyanın, bireylerin ve toplumun inanç, tavır, davranışlar ve değerleri üzerindeki etkisinin bilincinde olmaktır.

- Demokratik bir biçimde değişik medya kanalları yoluyla etkili iletişim kurmaktır (Özad, 2011, s. 89).

Medya endüstrisinin ticari bir işletme olarak çıkarları gereği "siyasal iktidarlarla" girebileceği 
ilişkiler bu tanımlamada "eleştiri" olarak sunulmaktadır. Oysa yukarıdaki tartışmalarda da yer yer değindiğimiz üzere, demokratik toplum anlatısı ve onun garantörlerinden biri olarak figüre edilmiş medya anlatısı, kapitalist toplum ve onun sömürüye dayalı eşitsiz ve özgürlüksüz yapılanmasına perde görevi görmektedir. Medya okuryazarlığı kavramının zaman zaman işaret ettiği, medyanın ticari yönü ve bundan doğan sorunlar bu perdeyi söküp atabilecek potansiyele sahip değildir; aksine liberal anlatının sistem yapısının şifrelerinin kırılmaması için kendisinin kontrolünde oluşturduğu yapay eleştirilerdir. Her sistemin devamlılığını sağlamak için kontrollü krizler ve buna yönelik çözümler ürettiği düşüncesi medya okuryazarlığı tanımlarını değerlendirmede bize yol gösterici olacaktır. Hatta başında "eleştirel" ifadesini taşıyan medya okuryazarlığı çalışmalarına karşı da temkinli olmamızı sağlayacaktır. Örneğin "Eleştirel Medya Okuryazarlı̆ı̆" isimli bir çalışmada, medya okuryazarlığının kapsamı bilgiye erişim, erişilen veya bize gönderilen iletileri çözümleyebilme, çözümlediğimiz iletileri birçok açıdan değerlendirebilme ve farklı iletişim kanal, araç ve tekniklerini kullanarak kendi iletilerimizi oluşturabilme/üretebilme alanındaki yeterliliklerdir" şeklinde oluşturulmuştur (Şahin, 2011, s.6). Bu kategorilerin açılımında da medyanın kendisinin üretim süreci ve yapısı ve bunun ürettiği ürüne yansıması, medyanın güç ve iktidar ilişkileri ile olan bağı ve bunun ürün üzerindeki etkisi konusunu deşifre edecek herhangi bir soru/sorunsal tespiti görülmemektedir. Kitapta çözümleme ve değerlendirme başlığı altında; şiddet sahnelerini tespit etme, önyargıları ve etiketleri belirleme, propaganda tekniklerini saptama, kamera hilelerini saptama, kahramanların ahlaki açıdan uygun davranıp davranmadıklarını belirleme, haberin doğruluğunu saptama, ürünün reklamda söylenenleri yapıp yapmadığını belirleme ve magazin programlarının gençler üzerindeki etkisini ifade etme, çözümleme ve değerlendirme kapsamı olarak sunulmuştur (Şahin, 2011, s.7). Örneğin bunlardan şiddet sahnelerini tespit etme konusunu ele alacak olursak, medya metinlerinde bireyi olumsuz etkileyebilecek şiddet içeriğini tespit etmek, anlamlı bir etkinlik olmakla beraber yeterli değildir. Hatta bunu ilerletip, metinde şiddetin nasıl çerçevelendiğine bakılsa dahi, doyurucu olmayacaktır. Ne zaman ki şiddeti tanımlama, onu meşru/gayrimeşru olarak tanımlamada belirleyici olan güç ve iktidar ilişkilerini ve bunun medya ile bağını ortaya çıkaran bir çözümleme yapılmasını içerir, işte o zaman o tanımlama gerçek anlamda bir eleştirellik sergileyecektir. Yine benzer bir biçimde, bir haberdeki en büyük sorun, onun doğru olup olmadığı konusu mudur? Ontolojik olarak olayın yaşanmış olması/olmaması haberdeki doğruluğu sağlar mı? Burada kapitalist pazarda haberin üretim süreci ve haberin kapitalist pazarın üretilme süreci ile olan ilişkisini ortaya koyan, güç ve iktidar ilişkilerinin metinde neden ve nasıl yer bulduğunu tespit etmek daha düşünümselliği yüksek bir değerlendirme olacaktır. Ya da kahramanların ahlaki açıdan uygun davranıp davranmadıklarını belirlemek konusunda, ilkin ahlak kavramının nasıl belirlendiğine bakarak, bunun nötr bir alan olmayıp, çoğu zaman güç/güçlüden yana evirildiğine ilişkin bir tartışmanın aralanıp, ardından bu bağlamda olay ve durumları genel standart kriterlerle değil de her birini kendi özgün şartları içinde değerlendirmek daha iyi bir analizi sağlayabilecektir. Son olarak ürünün reklamda söylenenleri yapıp yapmadığını belirlemek hangi seviyede bir eleştiriyi içinde barındırmaktadır? Bir reklamın birey ve toplum üzerindeki olumsuz yanı ticari açıdan ayıplı mal üretimi yapması 


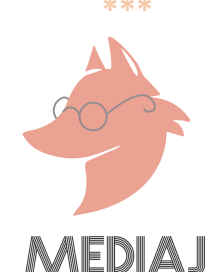

mıdır? Örneğin bir şampuan reklamında, şampuanın saçınızı ne denli hacimli göstereceğine dair bir ileti olduğunu düşünelim. Yukarıda bizler için istenilen eleştirel seviye, ürünün bunu sağlamaması halinde sadece bunu tespit etmek, belki bir ileri seviye olarak bununla ilgili "tüketici haklarından" yararlanma yönünde harekete geçmek ile sınırlıdır. Oysa bir reklamda yalnızca basit bir ürün tanıtımı yapıldığını düşünmek iyimserlik olacaktır. Reklam metinlerinde ürünün kullanım amacının haricinde size katkıları, esas üzerinde çözümleme yapmaya değer kısmını oluşturmaktadır. Örneğin bir şampuan reklamında bireye yıkadığımız şampuanın saçımızı temizlemesinin haricinde, bizi güzel ve arzu edilen bir bireye dönüştüreceği iması yapılmaktadır. Yani şampuanın kimyasal maddelerle dolu, doğallıktan uzak ve sağlığa zararlı olması bir tarafa, bize o ürünle elde edeceğimiz tatminin başka bir düzlemde yaşattırılması, reklamın esas sorunlu alandır. Bireyin mutluluğunu ve hedefini "güzel ve arzu edilebilir" olmakla kısıtlı tutan ve bireylerin ufuklarına yalnızca bunları "amaç ve hedef" olarak nakşeden bu anlayışı ve bu anlayışın tamamıyla pazarın dinamiklerinden kaynaklandığı gerçeğini deşifre eden bir çözümleme ve değerlendirme, "eleştirel" sıfatına layık olacaktır.

Görüldüğü gibi, kavramsallaştırılan medya okuryazarlığı başında "eleştirel" sıfatı taşıması halinde dahi çoğu zaman içerik olarak bunu karşılamamaktadır. Burada tartışılması gereken, bu yaklaşımların niyetidir. Daha açık bir deyişle, bunların sistem ile iş birliklerinin deşifresidir. Basit bir biçimde medya ile ilişkili üretilen bilimsel bilgiler ve bunlar sonucunda ulaşılan kavramsallaştırmaları belirli bir ideolojik duruştan azade tutmak, kavramların analizinde boşluk oluşturmaktadır. Bu noktada düşünülmesi gereken, kavramlarla ilişkiye girdiğimizde ona duyduğumuz güvenin sorguya açılmasıdır. Tanımlama ve kavramlaştırmalar birer çitleme gayretleridir. Bu gayretleri de belirleyen, egemen kılınmak istenen ideolojilerdir. Her bir tanım bu niyetleri taşır ve medya okuryazarlığı kavramsallaştırması da aynı şekilde bu niyetle tasarlanmıştır. Liberal anlatının tutucu ve muhafazakarlığının arazlarını benzer biçimde içinde hapseder. Kapitalist üretim biçim ve işleyişinin bir parçası olarak doğmuş olmasına karşın, bu sınıfsal çıkarlarla olan bağını perdeleyen liberal anlatının sistem bekçiliği için farklı an ve mekânlarda içsel tutarlılı̆a gerek duymaksızın ortaya serdiği çözümler bağlamında oluşturulan bu tanım ve kavramsallaştırmalar, liberal anlatının diğer bütün tanım ve kavramları gibi kutsanır ve yaygınlaştırılır. Aslında hiç olmadığı halde faydası varmış gibi sunulan bu kavramlar, doğaları gereği aslında bundan malul üretilirler. Birey ve toplumlara verdikleri diğer bir zarar da muhalif ya da eleştirel kontenjanını dolu göstermelerinden kaynaklanır. Muhalif ya da eleştirel olmanın sınırları bu kavramlarla çizilir, birey ve toplumlar bunlarla yetinir. Özetle kapitalist sistem, eleştirisini kendisine zarar vermeyecek dozda kendisi üretir; bireyleri ve toplumları de bu illüzyon içerisinde deşarj eder.

\section{SONUÇ VE DEĞERLENDIRME}

Okuryazarlığın ne ölçüde bir entelektüelliği içinde barındırdığını anlamak için tanımını gözden geçirmek gerekir. Okuryazar olmak, okuyup yazabilmek, okunan ögeleri algılama ve kavrama 
yetisine sahip olunması ${ }^{16}$ olarak tanımlanmaktadır. Tanımın ortaya koyduğu algı ve kavrama düzeyinin medya okuryazarlığında hedeflenen bilişsel düzeyi ne ölçüde karşıladığı üzerinde düşünülmesi gereken bir durumdur. Görüldüğü gibi tanım; analiz, çözümleme ve üretme gibi iddialı bir tavrı içermektedir. Fakat buna temel olabilecek, yani medyayı çözümlemek için gerekli olan medyanın ekonomi politiğinin deşifre edilmesi gereği tanımlarda karşılığını bulmamaktadır. Kavramsallaştırmaların çoğu, liberal çatıdan beslendiği için doğal olarak onun argümanlarından ilerlemektedir. Liberal anlatı medyayı da diğer pek çok kavrama yaptığı gibi, medyayı da esas köklerinden ayırıp, içine suni bir malzeme ile doldurmakta ve en önemlisi de ona "kamusal bir görev" yükleyerek, dokunulmazlık kisvesini de üzerine geçirmektedir. Buna ek olarak da medya toplum ilişkisinde, toplumun zihinsel yapılanmasında eğitimden sonraki en büyük belirleyen etken olması hedeflenen medyanın, hesap verilebilirliğini kolaylaştırıcı bir "kurtarıcı kavram" olarak, medya okuryazarlığı tanımını dolaşıma sokmakta, böylelikle birey yaşamında medyanın varlığı ve etkisi tartışılır olmaktan çıkarılmakta, en azından yine liberal anlatıda hâkim olan bakış açısıyla tutarlı bir biçimde birey her şeyden sorumlu hale getirilmektedir. Böylelikle, her şeyin izleyici hatasına indirgendiği/indirgeneceği medya okuryazarlığı anlatısı, eleştirel bir içeriğe sahip olup, medyanın yapısını ve işleyişini değiştirici ve dönüştürücü bir hedef çizmekten ziyade, tadilatlar önererek sistem için yararlı işlev görmektedir. Özetle; medya okuryazarlı̆̆ her ne kadar mevcut haliyle bireyi araştıran, sorgulayan ve üreten bir kişiye dönüştürme amacı ile donatılmıs olarak sunulsa dahi liberal anlatının hem bu üç kavrama yüklediği anlamların sığ ve dar olması nedeniyle, hem de sistemin asla kendi dinamiklerini tartışmaya açacak bir kavramı dolaşıma sokmayacağı gerçeği nedeniyle, medya okuryazarlığı ortaya koyduğu ideallerden oldukça uzak bir tasarım olarak karşımıza çıkmaktadır. Bunu açacak olursak, medya okuryazarlığının dört bileşeni olan erişim, çözümleme, değerlendirme ve üretim pratikte şu şekilde hayat bulmaktadır: İçeriği üreten araçlara erişebilme, eriştiği içeriğin kodladığı mesajı alabilme ve çözebilme, içeriği bireysel düzeyde analiz edebilme ve tüketim odaklı bir üretim gerçekleştirme. Oldukça düşük düzeyde bir belirleyiciliği içinde barındıran bu kapsam, medya okuryazarlığı ve onun toplum içerisindeki olası etkisi bakımından iyimser bir tablo çizmemektedir. Medya okuryazarlığı kavramı ne zaman medyanın kapitalist sistem ile bağını görünür kılma ve kapitalist sistemin güç ve iktidar ilişkilerindeki üstlendiği rolü deşifre etme ve üretim biçimi ve işleyişi yapısını eleştirme ve dönüştürme yönünde tanımlanıp, kavramsallaştırılırsa, "eleştirel" sıfatını taşımaya layık olacak ve medya okuryazarlığı bireyler ve toplumlar için ufuk açıcı bir eğitime dönüşebilecektir. Medya okuryazarlığının tatmin edici düzeyde bir "eleştirel"liği içinde taşıyacak hale getirilmesi için önce medya kavramının eleştirel kuramların ışığında ele alınması ile işe başlanmalıdır. Eleştirel kuramların medyanın üretim ilişkileri ile olan bağı kurması ve güç iktidar ilişkilerini deşifre etme gayreti, medyanın liberal anlatıda olduğunun aksine "dürüst bir biçimde tanımlanabilmesine imkân sağlayacak, ardından da tamlamanın tamlanan kısmı olan okuryazarlığı da buna bağlı olarak düzgün bir içerikle desteklenecektir. Hatta belki bu yeni çaba ile birlikte varılan noktada, medya okuryazarlığı

16 https://www. turkcebilgi. com/okuryazar. Erişim Tarihi: 09.10. 2020. 
kapitalist sistemin yapısını çözümleyebilen ve dönüştürücü çözümler sunabilen bir içerikle tasarlanacak, böylelikle de okuryazarlık kelimesinden ziyade entelektüellik gibi farklı ve yeni bir tamlanan ile kavramsallaştırılma yoluna dahi gidilebilecektir.

\section{KAYNAKÇA}

Alagözlü, Ç., (2013) Türkiye'de ve AB Ülkelerinde Medya Okuryazarlığı Örnek Incelemeler. Ankara: Pelikan Yayınları.

Alemdar, K. ve Erdoğan i. (1998). Başlangıcından Günümüze İletişim Kuram ve Araştırmaları. Ankara: MY Yayınları.

Aufderheide P. (1992). Media Literacy: A Report of the National Leadership Conference on Media Literacy. Washington, DC: Aspen Institute. http://www. medialit.org "/ reading_room/article356.html (Erişim Tarihi:28.01.2013).

Brüksel Deklarasyonu, http://www.declarationdebruxelles. be/en/ declaration_ accueil.php (Erişim Tarihi: 28.01.2013).

Dursun Ç. (2001). TV Haberlerinde İdeoloji. Ankara: Imge Kitabevi.

Dursun, Ç. (2013). Iletişim Kuram ve Kritik. Ankara: İmge Kitabevi.

https://www.tbmm.gov.tr/tutanaklar/KANUNLAR_KARARLAR/kanuntbmmc018/kanuntb mmc018/kanuntbmmc01803518.pdf. Erişim Tarihi:18.09.2019.

https://www.tbmm.gov.tr/tutanaklar/KANUNLAR_KARARLAR/kanuntbmmc033/kanuntb mmc033/kanuntbmmc03305680.pdf. Erişim Tarihi:18.09.2019.

https://www.Turkcebilgi.com/okuryazar. Erişim Tarihi: 09.10. 2020

Efe Özad, B. (2011). "Medya Okuryazarlığı ve Yetişkinlerin Öğrenmesi”. Nurçay Türkoğlu, Melda Cinman Şimşek (der.) Medya Okuryazarlığı. İstanbul: Parşomen Yayıncılık, s. 87-95.

Erdoğan, i. (2000). Kapitalizm, Kalkınma, Postmodernizm ve illetişim, Sömürünün Paketlenişi. Ankara: Erk Yayınları.

Erdoğan, i. (2002). Illetişimi Anlamak. Ankara: Erk Yayınları.

Erdoğan, i. \& Alemdar K. (2010). Öteki Kuram. Kitle iletişim Kuram ve Araştırmalarının Tarihsel ve Eleştirel Bir Değerlendirmesi. Yenilenmiş. 3. Baskı. Ankara: Erk Yayınları.

Freire, P. (2016). Ezilenlerin Pedagojisi. (Çev: Dilek Hattatoğlu). İstanbul: Ayrıntı Yayınları.

Koltay, T. (2011). "The Media and The Literacies: Media Literacy, Information Literacy, Digital Literacy". Media Culture Society, 33(2) s.211-221. 


\section{MEDIAJ}

Komisyon (2009). İlköğretim Medya Okuryazarlığı Ders Öğrenci Kitabı. Ankara: Sobil Yayınları.

Kovach, B. \& Rosenstiel T. (2007). Gazeteciliğin Esasları. Ankara: Odtü Geliştirme Vakfı Yayıncilık.

Öncel Taşkıran, N. (2007). Medya Okuryazarlığına Giriş. İstanbul: Beta Basım.

Şahin, A. (2011). Öğretmenler, Öğretmen Adayları ve Medya ile Bağı Olan Herkes İçin Eleştirel Medya Okuryazarlığı. Ankara: Anı Yayıncılık.

Taş, O. (2012). Gazetecilik Etiğinin Mesleki Sınırları. Profesyonellik, Piyasa ve Sorumluluk. İstanbul: İletişim Yayınları 